\title{
A Systematic Study on Physical and Mechanical Properties of No-Fine Concrete with Additives
}

\author{
T.S. Mukesh ${ }^{1, a^{*}}$, K. Thiru Vignesh ${ }^{2, b}$, S. Sri Rama Chandra Pradeep ${ }^{2, c}$, \\ R. Selva Bharathi ${ }^{2, d}$ \\ ${ }^{1}$ Assistant professor, Department of Civil Engineering, Kongu Engineering College, Perundurai, \\ Erode, Tamil Nadu, India \\ ${ }^{2}$ Student, Department of Civil Engineering, Kongu Engineering College, Perundurai, Erode, Tamil \\ Nadu, India \\ a*mukesh.sakthivel@gmail.com, bvignesh.26.125@gmail.com \\ csriramachandrapradeeps.17civil@kongu.edu, dselvabharathi3992@gmail.com
}

\section{Keywords: Additives, Porosity, Strength, Fly Ash, RCA, Rice Husk}

\begin{abstract}
No-fine concrete (also called as pervious concrete or porous concrete) is a lightweight concrete made up of primary binder and coarse aggregates with little or no sand. Due to the reduced amount or absence of fines, it produces large number of voids which improves permeability to greater extent. Hence this type of concrete can be used in pavements and in parking lots. The literature review is carried out to study the physical and mechanical properties of no-fine concrete with additives. Various reports were collected and studied about variation in physical and mechanical properties of pervious concrete with different additives. Additives may be either mineral additives (fly ash, silica fumes, rice husk ash etc..,) or chemical additives (plasticizers, super plasticizers, retarders etc..,). Our project involved the utilization of recycled coarse aggregates, fly ash and rice husk in no-fine concrete. After this study, it was concluded that 'upon the addition of additives, it increases permeability by decreasing its strength and vice-versa'. Balancing its permeability and strength remains challenging.
\end{abstract}

\section{Introduction}

In a recent study, it is revealed that India recycles only 1 percentage of C\&D (Construction and Demolition) waste [1]. India produces nearly 150 million tones of construction and demolition waste each year. These wastes often contain materials such as asphalt, gypsum, concrete debris, plastic etc.., Those things cannot be recycled easily because it may heavy, inert and bulk in nature. In addition to these wastes, some non-hazardous wastes are also produced in bulk quantity[2]. Our project involves the utilization of Recycled coarse aggregates, Fly ash and Rice huskin no-fine concrete (also called as pervious concrete or porous concrete). Two goals can be achieved by using those waste materials in concrete mix - Minimizing waste and adding some good properties in concrete [3]. Since the concept of green concrete is dominating now-a-days, it is necessary to utilize waste from all aspects to determine its capability. These alternatives also reduces the usage of natural resources such as sand, rock etc.., which enhances sustainable development to larger extent. Three types of specimen were used in our experiment. First type of specimen utilizes Recycled coarse aggregates (RCA) as a replacement for coarse aggregates. Typical porous concrete mix may consists of $185-360 \mathrm{~kg} / \mathrm{m}^{3}$ of primary binders, $1400-1600 \mathrm{~kg} / \mathrm{m}^{3}$ of coarse aggregates and $\mathrm{w} / \mathrm{c}$ ratio ranged from 0.27 to 0.45 . Usually fine aggregates will not be used in pervious concrete, as it may reduces permeable properties. But usage of little amount of fine aggregates may increases mechanical properties such as compressive strength, flexural strength 
etc.., Specimen without RCA and with few percent of RCA were casted and checked for porosity, compressive strength and flexural strength. Recycled concrete aggregates may absorb some amount of water which may results in decrease of workability. So super plasticizer is added for better workability. Second type of specimen utilizes fly-ash as an alternative for cement in concrete mix. Fly ash is a coal combustion product which can be used as a supplementary cementitious material (SCM) [4]. The use of fly ash in concrete has many advantages. It improves performance of concrete in both fresh and hardened state. It also improves workability, strength and durability of hardened concrete [5]. Fly ash is a cost-effective product which may decreases construction cost to some extent. Third type of specimen utilizes Rice-husk as fine aggregate in concrete mix. Rice-husks are the hard protective coverings of rice grains. It contains approximately 40 percent of cellulose, 30 percent of lignin and 20 percent of silica [2]. Presence of lignin and silica enhances strength of concrete. As previously said, usage of fine aggregate may decreases permeability but it increases mechanical properties. Some part of coarse aggregates is replaced by fine aggregates and rice husk and properties were compared with conventional pervious concrete.

\section{Materials}

The materials used in our project are Cement, Coarse aggregates, Fine aggregates, Recycled concrete Aggregates, Fly ash, Rice husks and water. Some basic properties of those materials are tested and their results were discussed below.

i) Cement: Cement is a primary binder which binds all other ingredients and sets and hardens independently. It is made by heating Calcium Carbonate $\left(\mathrm{CaCO}_{3}\right)$ with other materials such as clay in a rotating kiln with a temperature of $1723.15 \mathrm{~K}$. In this project 53 grade Ordinary Portland cement (OPC) is used and tested for specific gravity, Fineness, Consistency, Initial setting time and Final setting time. The properties obtained are as follows:

Table 2.1: Properties of cement

\begin{tabular}{|c|c|}
\hline Description & Test Values of OPC \\
\hline Specific Gravity & 3.13 \\
\hline Consistency & 31 \\
\hline Fineness & 9.3 \\
\hline Initial setting time & 36 minutes \\
\hline Final setting time & 606 minutes \\
\hline
\end{tabular}

ii) Coarse aggregates: Coarse aggregates usually occupies 75 to 80 percent of volume in concrete mix. The crushed stone aggregates passing through $40 \mathrm{~mm}$ sieve and retained in $20 \mathrm{~mm}$ sieve are collected and used in our experiment. The properties of Coarse aggregates were evaluated on the basis of procedures given in IS:383-1970 and IS:2386-1963 (Part I, Part II, Part III). The coarse aggregates were tested for specific gravity, Fineness modulus and grade limit and results obtained are as follows:

Table 2.2: Properties of coarse aggregates

\begin{tabular}{|c|c|}
\hline Description & Test Values \\
\hline Maximum size & $20 \mathrm{~mm}$ \\
\hline Specific gravity & 2.47 \\
\hline Fineness modulus & 7.2 \\
\hline Grade limit & Single sized aggregates \\
\hline
\end{tabular}


iii) Fine aggregates: Usage of fine aggregates in this type of concrete may improve mechanical properties. Manufactured sand (M-sand) were used. It is produced by crushing hard rocks or stones into small sand sized and angular shaped particles. M-sand is the best alternative for River sand. Aggregates passing through $4.75 \mathrm{~mm}$ sieve and retained in $2.36 \mathrm{~mm}$ sieve were used in our experiment. The fine aggregates were tested for specific gravity and fineness modulus. The results obtained are as follows:

Table 2.3: Properties of fine aggregates

\begin{tabular}{|c|c|}
\hline Description & Test Values \\
\hline Maximum size & $2.36 \mathrm{~mm}$ \\
\hline Specific gravity & 2.67 \\
\hline Fineness modulus & 3.06 \\
\hline
\end{tabular}

iv) Additives: Additives were used to improve the mechanical properties of concrete [6]. Three types of additives were used in three different specimens. They are Recycled concrete aggregates, Fly ash and rice husk. All these materials are tested for specific gravity and results obtained are as follows.

Table 2.4: Properties of additives

\begin{tabular}{|l|c|c|c|}
\hline Materials & R.C.A & Fly ash & Rice husk \\
\hline Specific Gravity & 2.71 & 2.8 & 2.13 \\
\hline
\end{tabular}

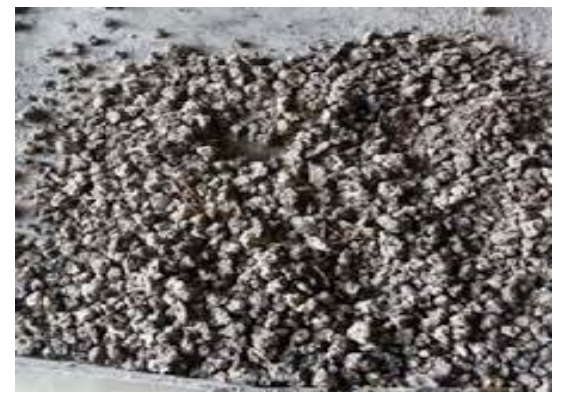

Fig 2.1: Concrete mix

\section{Testing of specimens:}

Various types of cube and prism specimen were casted with standard sizes and with suitable materials. The size of cube is $150 \mathrm{~mm} \times 150 \mathrm{~mm} \times 150 \mathrm{~mm}$ and that of prism is $500 \mathrm{~mm} \times 100 \mathrm{~mm} \times$ $100 \mathrm{~mm}$. The cube specimen were tested for compressive strength and porosityand prism specimen were tested for flexure strength. The calculated amount of cement, coarse aggregates, fine aggregates and additives were mixed with suitable water cement ratio and specimen were casted with proper damping. After casting, the specimen were demouldedand curing was done for 28 days using curing tank. After 28 days of curing the specimen were tested for compression, flexure and porosity. The properties of various specimen were studied and compared.

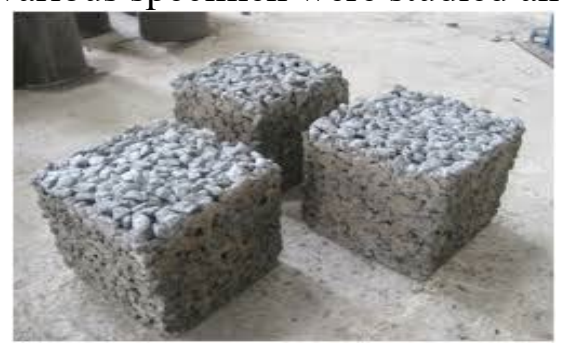

Fig 3.1: Cube specimen 


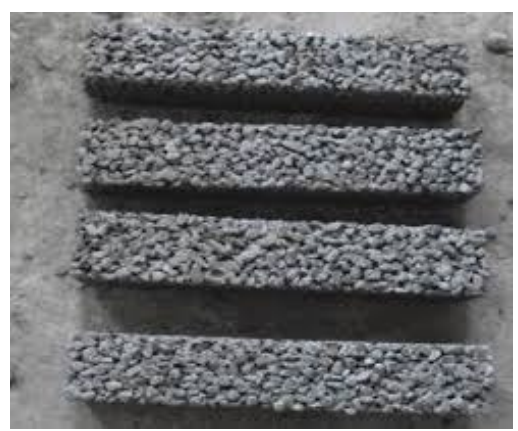

Fig 3.2: Prism specimen

Compressive strength: Compressive strength of a specimen is the capacity of a concrete to withstand loads tending to reduce size, as opposed to which withstand loads tending to elongate. As per BIS:516-1959 cubes of standard dimension $150 \mathrm{~mm} \times 150 \mathrm{~mm} \times 150 \mathrm{~mm}$ are tested in compressive testing machine of $3000 \mathrm{kN}$.The results obtaines are shown in Table 3.1 .Compressive strength can be calculated by using the formula

$$
\text { Compressive strength }=\frac{\text { Maximum load applied to the specimen in } \mathrm{kN}}{\text { Area of the specimen } \text { in }^{2}}
$$

Table 3.1: Compressive strength test results

\begin{tabular}{|c|c|c|c|c|c|c|c|c|}
\hline S.No & $\begin{array}{c}\text { Additive } \\
\text { used }\end{array}$ & $\begin{array}{c}\text { Weight } \\
\text { of } \\
\text { cement } \\
\text { (kg) }\end{array}$ & $\begin{array}{c}\text { Weight of } \\
\text { Coarse } \\
\text { aggregates } \\
\text { (kg) }\end{array}$ & $\begin{array}{c}\text { Weight of } \\
\text { Fine } \\
\text { aggregates } \\
\text { (kg) }\end{array}$ & $\begin{array}{c}\text { Percentage } \\
\text { of } \\
\text { additives }\end{array}$ & $\begin{array}{c}\text { Weight } \\
\text { of } \\
\text { additive } \\
\text { (kg) }\end{array}$ & $\begin{array}{c}\text { Load } \\
\text { (kN) }\end{array}$ & $\begin{array}{c}\text { Compressive } \\
\text { strength } \\
\mathbf{( N / m m} \text { ) }\end{array}$ \\
\hline 1. & None & 2 & 6 & 0 & - & - & 226 & 10.04 \\
\hline 2. & None & 2 & 4.8 & 1.2 & - & - & 231 & 10.27 \\
\hline 3. & R.C.A & 2 & 5.7 & 0 & 5 & 0.3 & 224 & 9.96 \\
\hline 4. & R.C.A & 2 & 5.4 & 0 & 10 & 0.6 & 228 & 10.13 \\
\hline 5. & R.C.A & 2 & 5.1 & 0 & 15 & 0.9 & 227 & 10.09 \\
\hline 6. & R.C.A & 2 & 4.8 & 0 & 20 & 1.2 & 225 & 10.0 \\
\hline 7. & Fly ash & 1.9 & 6 & 0 & 5 & 0.1 & 225 & 10.0 \\
\hline 8. & Fly ash & 1.8 & 6 & 0 & 10 & 0.2 & 227 & 10.09 \\
\hline 9. & Fly ash & 1.7 & 6 & 0 & 15 & 0.3 & 228 & 10.13 \\
\hline 10. & Fly ash & 1.6 & 6 & 0 & 20 & 0.4 & 226 & 10.04 \\
\hline 11. & Rice Husk & 2 & 4.8 & 1.14 & 5 & 0.06 & 230 & 10.22 \\
\hline 12. & Rice Husk & 2 & 4.8 & 1.08 & 10 & 0.12 & 228 & 10.13 \\
\hline 13. & Rice Husk & 2 & 4.8 & 1.02 & 15 & 0.18 & 226 & 10.04 \\
\hline 14. & Rice Husk & 2 & 4.8 & 0.96 & 20 & 0.24 & 224 & 9.96 \\
\hline
\end{tabular}




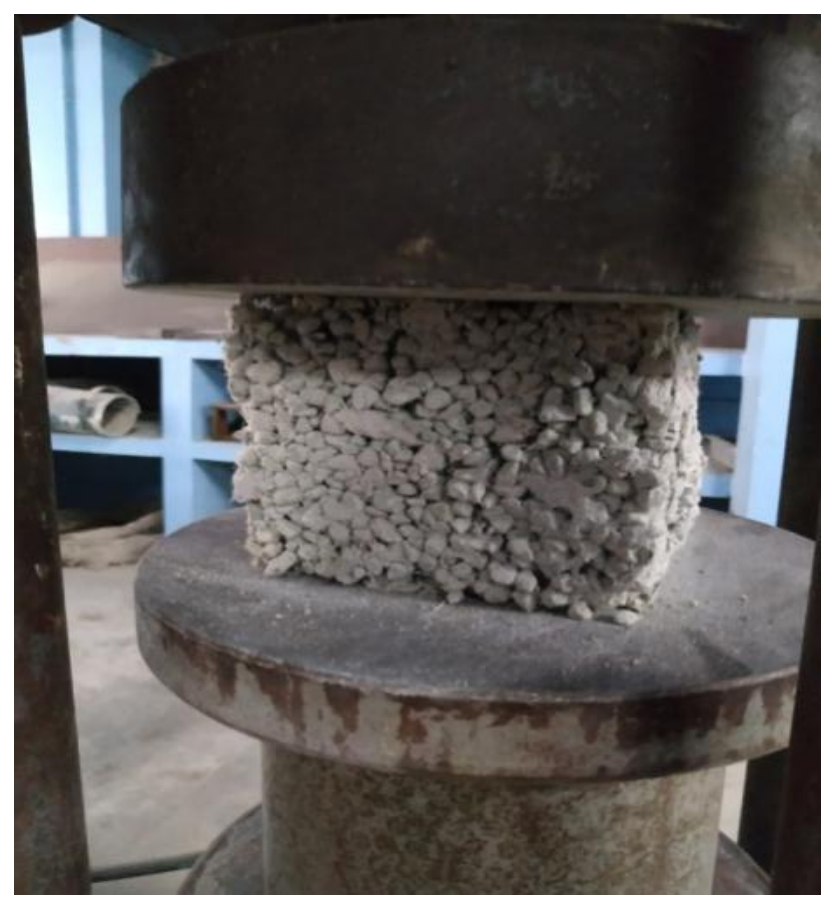

Fig 3.3: Compression test

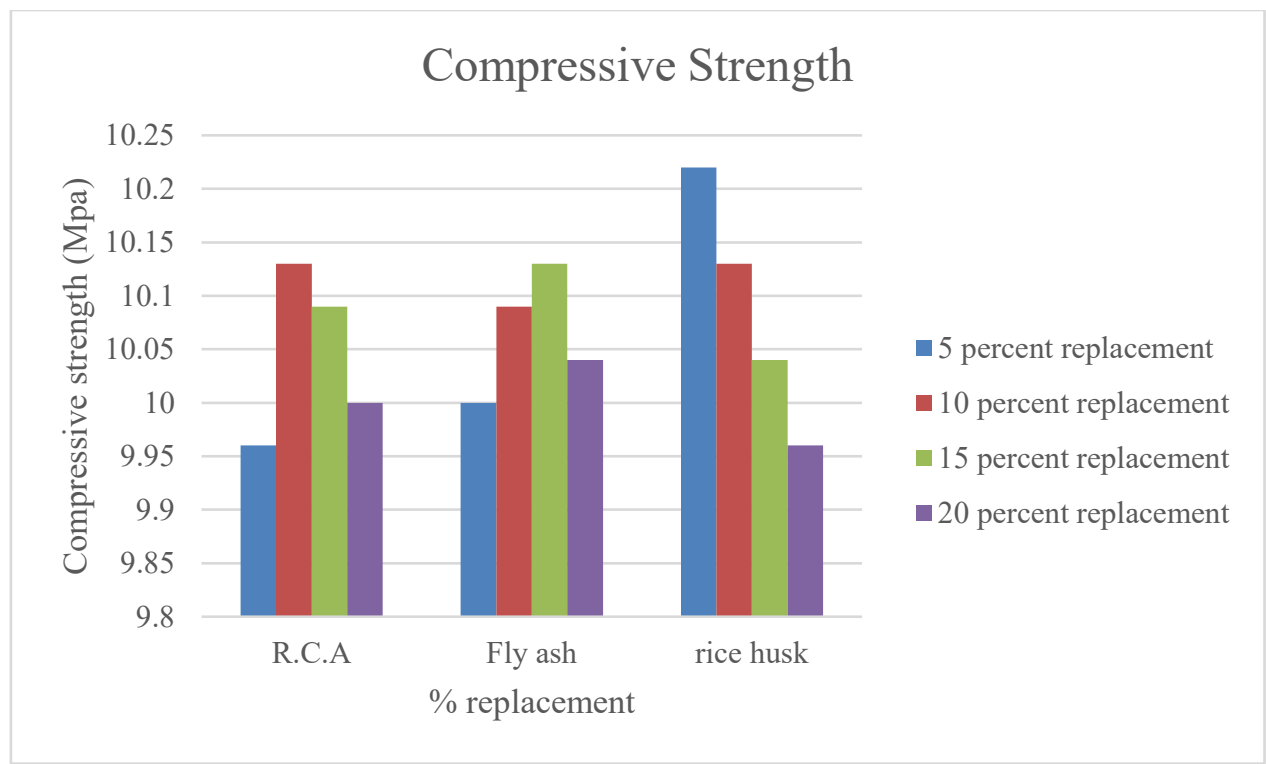

Fig 3.4: \% replacement vs Compressive strength chart

Inference: The compressive strength test of specimens revealed that upon the addition of additives suitably, there is an improvement in compressive strengths than conventional concrete. Over usage of additives in concrete mix decreases compressive strength. It is appreciable to replace 10 percent of coarse aggregates by RCA and 15 percent of cement by fly ash and just 5 percent of fine aggregate by rice husk to yield better compressive strength which will be higher than conventional porous concrete.

Flexural strength: Flexural strength is a property of a material which is defined as the stress in a material just before it yields in a flexure strength. Concrete is strong in compression but weak in 
tension. Prism specimen of dimensions $500 \mathrm{~mm} \times 100 \mathrm{~mm} \times 100 \mathrm{~mm}$ were casted and tested in flexural strength testing machine. Flexural strength can be calculated by using the formula

Flexural strength $=(\mathrm{P} \times \mathrm{L}) /\left(\mathrm{B} \times D^{2}\right)$, where

$\mathrm{P}=$ Load applied in $\mathrm{kN}$

$\mathrm{L}=$ Length of the specimen in $\mathrm{mm}$

$\mathrm{B}=$ Breadth of the specimen in $\mathrm{mm}$

$\mathrm{D}=$ Depth of the specimen in $\mathrm{mm}$

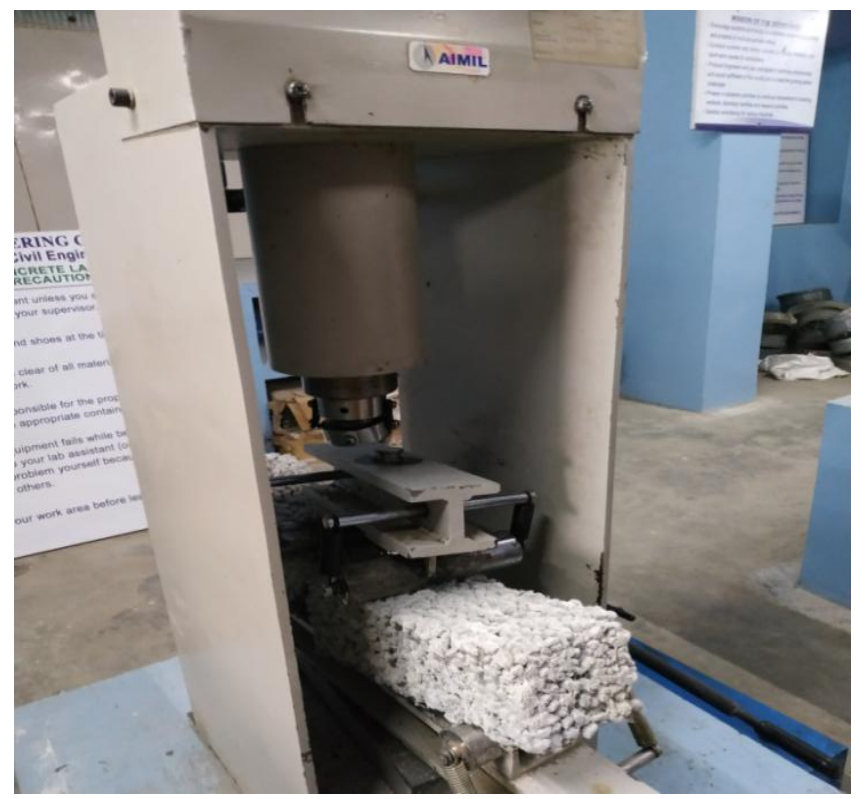

Fig 3.5: Flexural test

The results obtained are shown in Table 3.2

Table 3.2: Flexural strength test results

\begin{tabular}{|c|c|c|c|c|c|c|c|c|}
\hline S.No & $\begin{array}{c}\text { Additive } \\
\text { used }\end{array}$ & $\begin{array}{c}\text { Weight } \\
\text { of } \\
\text { cement } \\
\text { (kg) }\end{array}$ & $\begin{array}{c}\text { Weight of } \\
\text { Coarse } \\
\text { aggregates } \\
\text { (kg) }\end{array}$ & $\begin{array}{c}\text { Weight of } \\
\text { Fine } \\
\text { aggregates } \\
\text { (kg) }\end{array}$ & $\begin{array}{c}\text { Percentage } \\
\text { of } \\
\text { additives }\end{array}$ & $\begin{array}{c}\text { Weight } \\
\text { of } \\
\text { additive } \\
\text { (kg) }\end{array}$ & $\begin{array}{c}\text { Load } \\
\text { (kN) }\end{array}$ & $\begin{array}{c}\text { Flexural } \\
\text { strength } \\
\text { (N/mm } \mathbf{m m}^{\mathbf{2}} \text { ) }\end{array}$ \\
\hline 1. & None & 3.125 & 9.375 & 0 & - & - & 2.1 & 1.05 \\
\hline 2. & None & 3.125 & 7.5 & 1.875 & - & - & 2.3 & 1.15 \\
\hline 3. & R.C.A & 3.125 & 8.906 & 0 & 5 & 0.469 & 1.9 & 0.95 \\
\hline 4. & R.C.A & 3.125 & 8.438 & 0 & 10 & 0.937 & 2.2 & 1.1 \\
\hline 5. & R.C.A & 3.125 & 7.969 & 0 & 15 & 1.406 & 2.0 & 1.0 \\
\hline 6. & R.C.A & 3.125 & 7.5 & 0 & 20 & 1.875 & 1.7 & 0.85 \\
\hline 7. & Fly ash & 2.969 & 9.375 & 0 & 5 & 0.156 & 2.0 & 1.0 \\
\hline 8. & Fly ash & 2.812 & 9.375 & 0 & 10 & 0.313 & 2.2 & 1.1 \\
\hline 9. & Fly ash & 2.656 & 9.375 & 0 & 15 & 0.469 & 2.3 & 1.15 \\
\hline 10. & Fly ash & 2.5 & 9.375 & 0 & 20 & 0.625 & 2.1 & 1.05 \\
\hline 11. & Rice Husk & 3.125 & 7.5 & 1.781 & 5 & 0.094 & 2.0 & 1.0 \\
\hline 12. & Rice Husk & 3.125 & 7.5 & 1.687 & 10 & 0.188 & 1.8 & 0.9 \\
\hline 13. & Rice Husk & 3.125 & 7.5 & 1.594 & 15 & 0.281 & 1.6 & 0.8 \\
\hline 14. & Rice Husk & 3.125 & 7.5 & 1.5 & 20 & 0.375 & 1.3 & 0.65 \\
\hline
\end{tabular}




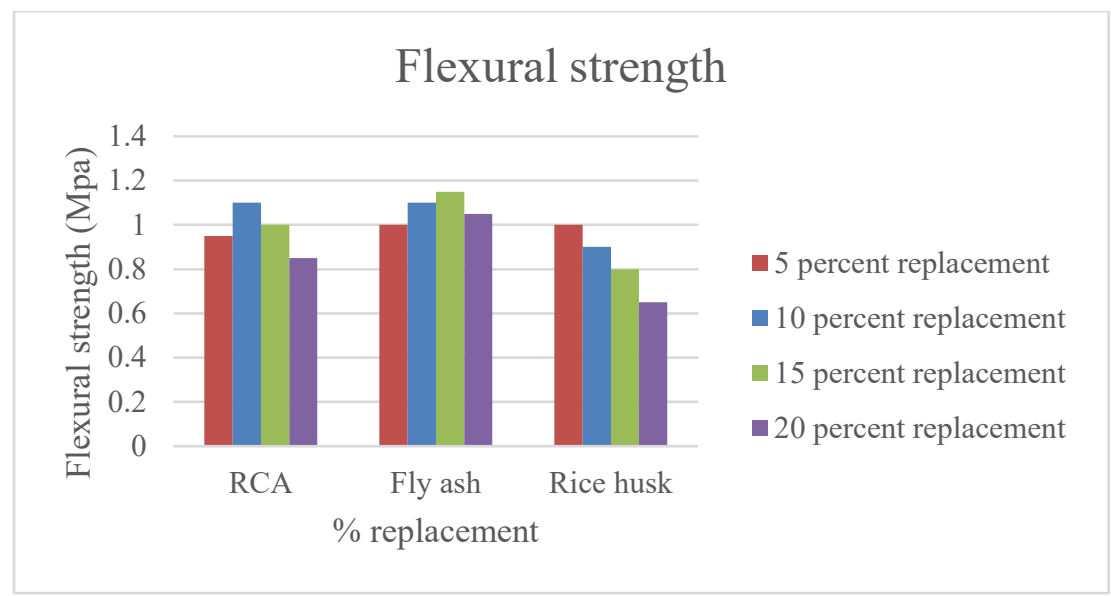

Fig 3.6: \% replacement vs Flexural strength chart

Inference: The flexural strength test of specimens revealed that upon the addition of additives suitably, there is an improvement in flexural strengths than conventional concrete. Over usage of additives in concrete mix decreases flexural strength. As similar to that of compressive strength results it is also appreciable to replace 10 percent of coarse aggregates by RCA and 15 percent of cement by fly ash and just 5 percent of fine aggregate by rice husk to yield better flexural strength which will be higher than conventional porous concrete.

Porosity: Porosity is the measure of the void spaces in a concrete specimen, and it is the ratio of volume of voids to total volume. It is expressed in percentage and varies from 0 percent to 100 percent. Cube specimen of dimensions $150 \mathrm{~mm}$ x $150 \mathrm{~mm} \times 150 \mathrm{~mm}$ were used in porosity test. The specimens were immersed in known volume of water in a container for about 24 hours. By measuring the variation in water level before and after immersion, the volume of water replaced by the sample $\left(V_{r}\right)$ can be calculated. Subtracting $V_{r}$ from bulk volume $(V)$, volume of open pores can be found. Hence porosity can be calculated by the formula

$$
\text { Porosity percentage }=\frac{V_{r}-V}{V_{r}} \times 100
$$

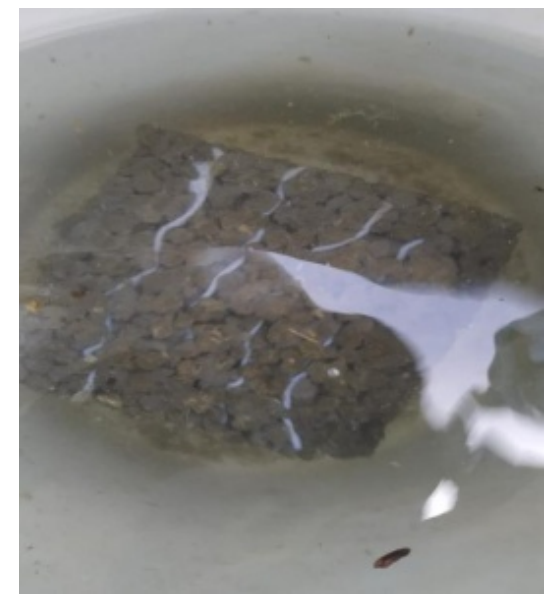

Fig 3.7: Porosity test

The results obtained are shown in Table 3.3 
Table 3.3: Porosity test results

\begin{tabular}{|c|c|c|c|c|c|c|c|}
\hline S.No & $\begin{array}{c}\text { Additive } \\
\text { used }\end{array}$ & $\begin{array}{c}\text { Weight } \\
\text { of } \\
\text { cement } \\
\text { (kg) }\end{array}$ & $\begin{array}{c}\text { Weight of } \\
\text { Coarse } \\
\text { aggregates } \\
\text { (kg) }\end{array}$ & $\begin{array}{c}\text { Weight of } \\
\text { Fine } \\
\text { aggregates } \\
\text { (kg) }\end{array}$ & $\begin{array}{c}\text { Percentage } \\
\text { of } \\
\text { additives }\end{array}$ & $\begin{array}{c}\text { Weight } \\
\text { of } \\
\text { additive } \\
\text { (kg) }\end{array}$ & $\begin{array}{c}\text { Porosity } \\
\text { \% }\end{array}$ \\
\hline 1. & None & 2 & 6 & 0 & - & - & 39.6 \\
\hline 2. & None & 2 & 4.8 & 1.2 & - & - & 37.4 \\
\hline 3. & R.C.A & 2 & 5.7 & 0 & 5 & 0.3 & 37.1 \\
\hline 4. & R.C.A & 2 & 5.4 & 0 & 10 & 0.6 & 36.2 \\
\hline 5. & R.C.A & 2 & 5.1 & 0 & 15 & 0.9 & 34.8 \\
\hline 6. & R.C.A & 2 & 4.8 & 0 & 20 & 1.2 & 33.7 \\
\hline 7. & Fly ash & 1.9 & 6 & 0 & 5 & 0.1 & 38.5 \\
\hline 8. & Fly ash & 1.8 & 6 & 0 & 10 & 0.2 & 37.2 \\
\hline 9. & Fly ash & 1.7 & 6 & 0 & 15 & 0.3 & 35.9 \\
\hline 10. & Fly ash & 1.6 & 6 & 0 & 20 & 0.4 & 34.3 \\
\hline 11. & Rice Husk & 2 & 4.8 & 1.14 & 5 & 0.06 & 32.6 \\
\hline 12. & Rice Husk & 2 & 4.8 & 1.08 & 10 & 0.12 & 31.4 \\
\hline 13. & Rice Husk & 2 & 4.8 & 1.02 & 15 & 0.18 & 29.7 \\
\hline 14. & Rice Husk & 2 & 4.8 & 0.96 & 20 & 0.24 & 28.1 \\
\hline
\end{tabular}

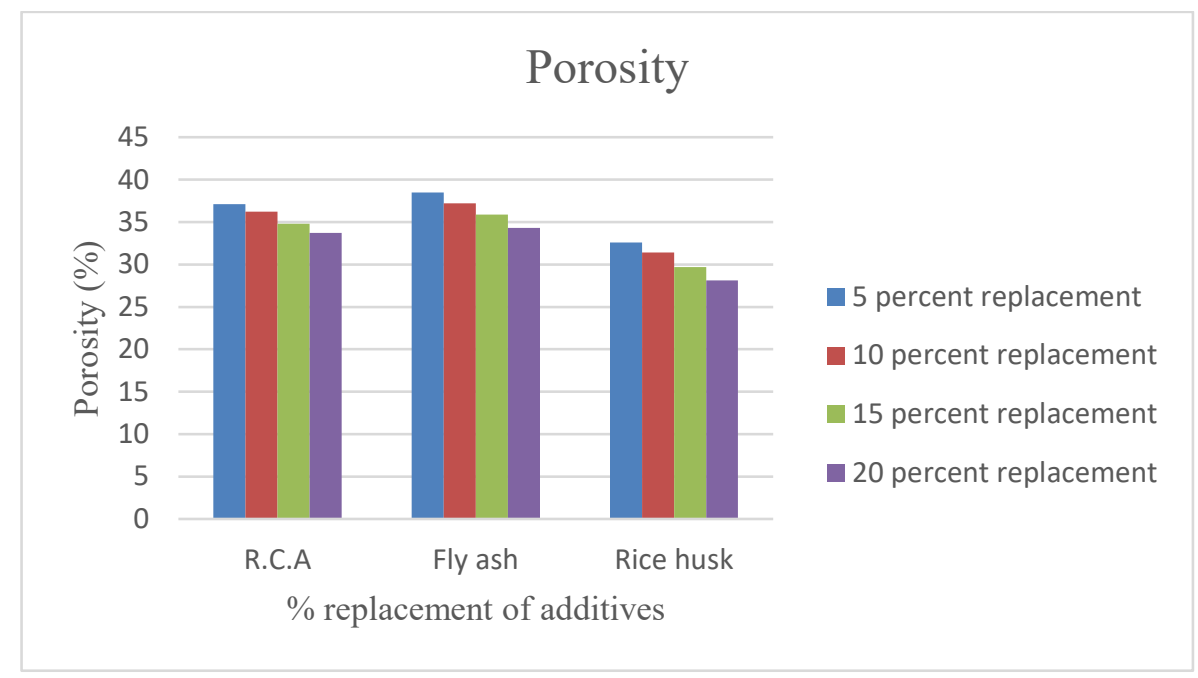

Fig 3.8: \% replacement vs Porosity chart

Inference: The variation in porosity results were studied for pervious concrete with different additives. It is concluded that the porosity decreases even with the addition of small quantity of additives. Only the conventional porous concrete possess good porosity results. Replacement of coarse aggregates by RCA nearly maintains the porosity. Addition of finer particle additives like fly ash and rice husk arrests the voids in porous concrete which in turn decreases porosity. But decrease in voids content due to addition of additives will increase mechanical properties like compressive strength and flexural strength. It is also concluded that porosity is inversely proportional to percentage of additives added. 


\section{Conclusion and results:}

The addition of various types of additives in porous concrete yields different results. Anyhow, the results obtained are in accordance with the acceptable limits. These type of concrete can be used in parking lots to improve ground water level. The pores in this concrete arrests the rain water run-off. In addition to this, the following conclusions are made.

1. The conventional pervious concrete possess high percentage of porosity when compared to those with additives. Adding additives decreases voids which in turn decreases porosity. But conventional porous concrete has low compressive and flexural strength comparatively.

2. Adding small amount of fine aggregates in a concrete mix decreases porosity by increasing its strength.

3. Replacing coarse aggregate by recycled concrete aggregate upto 10 percent gives good mechanical properties, but decreases porosity.

4. Replacing cement by fly ash upto 15 percent yields good mechanical properties (not greater than recycled concrete aggregates). This replacement also decreases porosity.

5. Replacing fine aggregates by rice husk does not improve mechanical properties and porosity. Hence this type of concrete cannot be used in heavy load applications due to its low strength.

\section{References}

[1] "Effects of rice husk ash and fibre on mechanical properties of pervious concrete pavement"-S Hesami, S Ahmadi, M Nematzadesh-Construction and building materials,2014.

[2] "Effects of Rice Husk ash on properties of pervious concrete"-S Talsania, J Pitroda,C M Vyas. 2015.

[3] "Properties of pervious concrete containing fly ash"- Y Aoki, R Sri Ravindrarajah-materials and pavement-2012.

[4] "Studies on the properties of pervious fly ash-cement concrete as a pavement material"-UM Muthaiyan, S Thirumalai- Cogent Engineering-2017.

[5] "Properties of pervious concrete containing recycled concrete block aggregate and recycled concrete aggregate"- Y Zaetang, V Sata, A Wongsa-Construction and building materials-2016.

[6] "Suistainable Design of Pervious concrete using waste glass and Recycled concrete aggregates”- J X Lu, Xyam, P He, C S Poon,Journal of cleaner production, 2019.

[7] "Influence of recycled aggregate replacement and fly ash content in performance of Pervious concrete mixes"-G L Vieira, J Z Schiavon, P M Borges, S R da Silva,Journal of cleaner production-2020. 